\title{
Indigenous knowledge and local practices concerning the endemic plant lpo- moea beninensis Akoègn., Lisowski \& Sinsin (Convolvulaceae): an initial as- sessment for its conservation in Benin
}

\author{
Received: 2020-04-10; revised: 2020-10-28; accepted: 2020-10-31
}

\author{
Hospice Gbèwonmèdéa Dassou ${ }^{1 *}$, Rodrigue Idohou ${ }^{2,3}$, Aristide Cossi Adomou ${ }^{1}$, Jéronime Marie-Ange Sènami \\ Ouachinou ${ }^{1}$, Hounnankpon Yédomonhan ${ }^{1}$
}

\author{
${ }^{1}$ Laboratoire de Botanique et Ecologie Végétale, Faculté des Sciences et Techniques, Université d'Abomey-Calavi, 01 BP \\ 4521 Cotonou, République du Bénin. \\ ${ }^{2}$ Laboratoire de Biomathématiques et Estimations Forestières, Faculté des Sciences Agronomiques, Université d'Abomey- \\ Calavi. 04 BP 1525 Cotonou (Benin). \\ ${ }^{3}$ Ecole de Gestion et de Production Végétale et Semencière, Université Nationale d'Agriculture, Kétou, République du Bé- \\ nin. \\ *Corresponding author. E-mail: daspice2@gmail.com
}

\begin{abstract}
Summary: Ipomoea beninensis Akoègn., Lisowski \& Sinsin (Convolvulaceae) is the only endemic plant known for Benin. To date, no data exist on its usages, distribution, abundance, and threats. An improved understanding of indigenous knowledge and of local practices can provide insight into how the species could be sustainably conserved. We interviewed 114 local residents for collecting ethnobotanical and ethnoecological data in six sites known to host the species. Data were processed by calculation of descriptive statistics and variance and multivariate analyses. A total of twelve uses were reported. Among them, treatment of varicella (19\%), malaria (18\%) and fodder (17\%) were the most recurrent. These mainly involve use of the species rootstock. Almost all respondents mentioned decline of the species in natural habitats. None of them was aware about the endemic status of the species. Consequently, negative practices toward the protection of $I$. beninensis were prevalent among local residents. Several conservation measures are proposed to ensure the longterm survival of $I$. beninensis.

Key words: Ipomoea beninensis, resident' knowledge and perceptions, negative practices, endemism, conservation, Benin.

\section{CONNAISSANCES TRADITIONNELLES ET PRATIQUES LOCALES SUR UNE ESPÈCE ENDÉMIQUE IPOMOEA BENI- NENSIS AKOĖGN., LISOWSKI \& SINSIN (CONVOLVULACEAE): UNE ÉVALUATION PRÉLIMINAIRE POUR SA CON- SERVATION AU BÉNIN}

Résumé: Ipomoea beninensis Akoègn., Lisowski \& Sinsin (Convolvulaceae) est la seule plante endémique connue pour le Bénin. A ce jour, aucune donnée n'existe sur ses usages, sa distribution, son abondance et ses menaces. Une meilleure compréhension des connaissances autochtones et des pratiques locales peut donner un aperçu de la manière dont l'espèce pourrait être conservée de manière durable. Des interviews ont été réalisées auprès de 114 résidents locaux pour la collecte de données ethnobotaniques et ethnoécologiques dans six localités. Les données ont été traitées par le calcul de statistiques descriptives et d'analyses de variance et multivariées. Au total, douze utilisations ont été signalées parmi lesquelles le traitement de la varicelle $(19 \%)$, du paludisme (18\%) et le fourrage (17\%) étaient les plus rapportées. Ces derniers impliquent principalement l'utilisation des racines de l'espèce. Presque tous les enquêtés ont mentionné le déclin de l'espèce dans les habitats naturels. Aucun d'entre eux n'est au courant du statut endémique de l'espèce. Par conséquent, les pratiques négatives à l'encontre de la protection de I. beninensis étaient répandues. Plusieurs mesures de conservation sont proposées pour assurer la survie à long terme de I. beninensis.

Mots clés: Bénin, connaissances et perceptions locales, conservation, endémisme, Ipomoea beninensis, pratiques négatives.

\section{Indigenes Wissen und lokale Praktiken in Bezug auf die endemische Pflanze Ipomoea beninen- SIS AKOĖGN., LISOWSKI \& SINSIN (CONVOLVULACEAE): EINE ERSTE BEWERTUNG FÜR IHRE ERHALTUNG IN BENIN}

Zusammenfassung: Ipomoea beninensis Akoègn., Lisowski \& Sinsin (Convolvulaceae) ist die einzige für Benin bekannte endemische Pflanze. Bisher existieren keine Daten zu Verwendung, Verbreitung, Häufigkeit und Bedrohungen dieser Art. Da ein verbessertes Verständnis des indigenen Wissens und lokaler Praktiken für die Erhaltung bedeutsam sein kann, wurden diesbezüglich an sechs Standorten der Art insgesamt 114 Einheimische interviewt. Die statistische Bearbeitung der gesammelten Daten erfolgte mittels deskriptiver Statistiken und Varianz- und multivariater Analysen. Insgesamt wurden zwölf Verwendungen gemeldet. Am häufigsten genannt wurden Behandlung von Varizellen (19\%), Malaria (18\%) und Futter $(17 \%)$, wobei hauptsächlich der Wurzelstock verwendet wird. Fast alle Befragten erwähnten den Rückgang der Art. Keiner von ihnen war sich des endemischen Status der Art bewusst. Folglich sind für bei den Einheimischen Praktiken weit verbreitet, die sich negativ auf den Bestand von Ipomoea beninensis auswirken. Es werden verschiedene Erhaltungsmaßnahmen vorgeschlagen, um das langfristige Überleben von I. beninensis sicherzustellen.

Schlagworte: Ipomoea beninensis, Wissen und Wahrnehmung der Einheimischen, Nutzung, negative Praktiken, Endemismus, Artenschutz, Benin. 


\section{INTRODUCTION}

Worldwide, a limited number of species are confined to a small area. For instance, of the 9,000 plant species harboured by the Guineo-Congolese humid forests, only 1,800 of them $(20 \%)$ are confined to this ecosystem (CONSERVATION INTERNATIONAL DATABASE 2005). Thus, the endemism refers to a species that is restricted to a particular geographic region (island, a country or other defined space or habitattype) as a result of factors such as isolation or in response to abiotic conditions. In general, species that are confined to a specific area represent interesting targets in ecology, evolutionary biology and genetic (ECKERT et al. 2008; PouGET et al. 2013; SEXTON et al. 2009). As suggested by the International Union for the Conservation of Nature (IUCN), such a special biodiversity deserves a conservation program because with its very restricted natural range, it is especially vulnerable to extinction if its natural habitat is eliminated or significantly disturbed (IUCN 2019). Unfortunately, knowledge, documentation and conservation program of these species above all tropical species follow the opposite trend, and sometimes they remain unidentified. Yet, these plants associated with other wild plants constitute as well as resources essential for subsistence and cash economies as ecologically important elements. Generally, wild plant resources are harvested by local people for a variety of purposes including construction materials, household tools, medicine, food, income generation and rituals. Nowadays evidence shows that the over-exploitation of these resources is among causes of biological diversity decline at local, national or international level (BотнA et al. 2004; TiсктіN 2004; Gaoué \& Ticktin 2007; Schmidt et al. 2011; Schumann et al. 2011; GAOUÉ et al. 2017). The situation is more critical when endemic species are of concern.

The flora of Benin contains 2807 plant species belonging to 1130 genera and 185 families (AKoÈGNINOU et al. 2006), among them three highly narrow-distribution species, but only one (Ipomoea beninensis Akoègn., Lisowski \& Sinsin, Convolvulaceae) is confined to Benin area. The two others previously considered to be Beninese endemic namely Thunbergia atacorensis Akoègn. \& Lisowski (Acanthaceae) and Cyperus beninensis (Samain, Reynders \& Goetgh.) Huygh (Cyperaceae) also grow in Togo (Fandohan et al. 2015) and Burkina Faso (Schmidt 2018), two neighbouring countries.

The genus Ipomoea comprises 37 species distributed across climate zones and different habitats in Benin and has been poorly studied except for its description in the national flora (AKoÈGNINOU et al. 2006). Among those species is the endemic taxon I. beninensis, for which the known area extends from the Guineo-Sudanian to the Sudanian zones in Benin (AKoÈGNINOU et al. 2006). It is a plant with ecological, social and cultural values, playing a significant role in local peoples' needs, mainly in rural areas. Its populations have been mis-managed for years by bush fire affecting the availability of its aerial parts (stem and leaves) for uses by local people, changes in land uses and overexploitation of its rootstocks (Pers. obser.). Apart from DO-REGO (2017) which mentioned the presence of only few populations of the species in its distributional area and in spite of its endemic status and its importance for local population, little is documented regarding the knowledge held by rural populations and its especial biogeographic interest. Yet, the report of traditional knowledge is important in the course of a broad range of questions related to the relationship between humans and nature (Souto \& TICKTIN 2012). The relationship between plant species and their use by local communities is recognized as a central question in conservation science. A deeper understanding of the use of species by rural communities has become a major concern in ethnobotanical studies. We can cite HaHn et al. (2018) who investigated edible wild plants on the national scale of Burkina Faso to provide a comprehensive overview of plant parts of all edible plants in order to plan their sustainable use. This knowledge is important as it will shape future conservation plan targeting the species and other similar species. Thus, assessing the knowledge that local people hold on Ipomoea species is crucial as this information is useful in the efficient estimation of the uses at a local level while considering different cultures across the study area.

The main objective of this study was to document the traditional knowledge of I. beninensis to be used for its sustainable management in Benin. Research questions in the frame of the current study are as follow:

1. Which knowledge do local people have on I. beninensis?

2. Which plant parts of the species are the most important for the local population?

3. Do the sociolinguistic group, gender, age, and education of the informants affect uses of the species?

4. What are local people's perceptions on threats and conservation status of the species?

\section{MATERIAL AND MethodS}

\subsection{Study area}

This study was carried out in six sites (Djougou, Natitingou, Tanguiéta, Toucountouna, N'Dali and Pèrèrè) (Fig. 1) known to host $I$. beninensis (AkoÈGNINOU et al. 2006). They are located in two ecological areas: transitional or Guineo-Sudanian $\left(7^{\circ} 30^{\prime} \mathrm{N}\right.$ to $\left.9^{\circ} 45^{\prime} \mathrm{N}\right)$ and Sudanian $\left(9^{\circ} 45^{\prime} \mathrm{N}\right.$ to $\left.12^{\circ} 25^{\prime} \mathrm{N}\right)$ areas in Benin (Fig. 1). With the exception of the Atacora chain (400-513 meters [m] above sea level), the region mostly lies between 150-200 m above sea level (HeinRICH \& Moldenhauer 2002). The mean annual rainfall varies between 1150 and $1300 \mathrm{~mm}$ in this area. Relative humidity ranges between $31-98 \%$ in the Guineo-Sudanian zone (GSZ) and 18-99\% in the Sudanian zone (SZ). The average annual temperature is $26-28^{\circ} \mathrm{C}$. In the GSZ, the vegetation is dominated by Isoberlinia woodlands whereas it is characterized by Combretum and Acacia tree savannahs in the SZ. All studied localities include modified environments such as home gardens and farming lands. Soils are ferruginous with intrusions of ferralitic soils (GSZ) and on sedimentary rocks (SZ) (Adomou 2005). The main sociolinguistic groups in GSZ are Fon and related sociolinguistic groups $(42 \%)$, Adja and related sociolinguistic groups $(16 \%)$ and Yoruba and related sociolinguistic groups (12\%). 

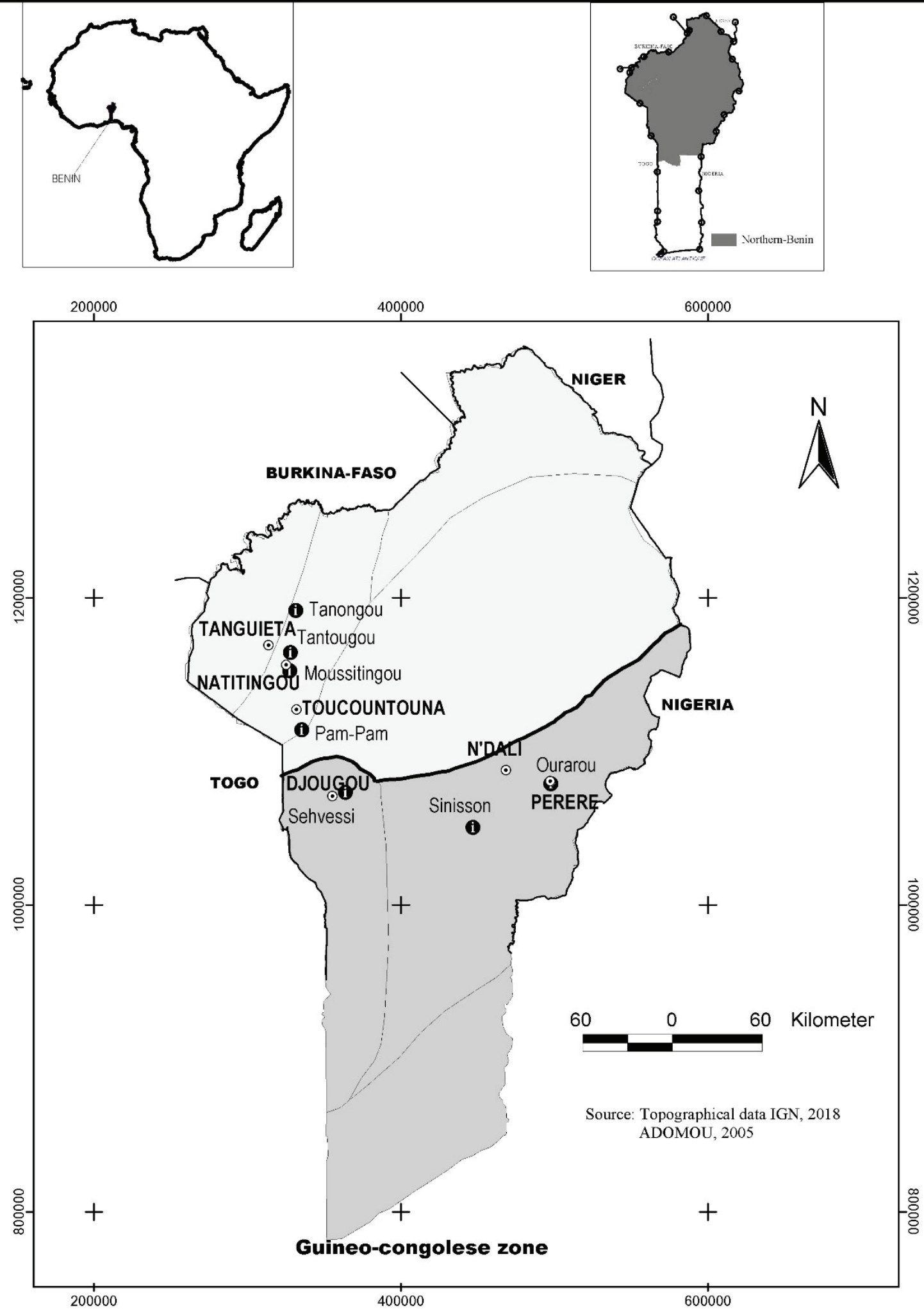

( Prospected villages

$\odot \quad$ Major cities

Guineo-Sudanian zone

Boundary between Sudanian and

Guineo-Sudanian zones

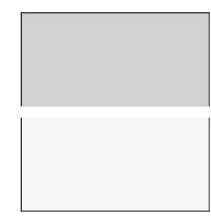

Sudanian zone

Fig. 1: Map of the republic of Benin showing the chorological areas and the study villages. / Carte de la république du Bénin montrant les zones chorologiques et les villages d'étude. 
In the SZ the inhabitants are Bariba and related sociolinguistic groups (9\%), Betammaribè and related sociolinguistic groups (6\%), Peulh and related sociolinguistic groups (6\%). In both zones, the main economic activity practiced by people is agriculture (INSAE 2013) which threatens biodiversity and subsequently leads to the loss of species. Thus, the conservation of biodiversity is essential to ensure their availability for the subsistence and cash incomes of rural people in the future.

\subsection{Study species}

I. beninensis (Fig. 2) was discovered in 1999 during botanical research (AKoÈGNINOU \& LISOWSKI 2004) in the framework of "Flora project of Benin". It is a glabrous perennial



Fig. 2: Ipomoea beninensis; in a fallow at Toucountouna - photo G.H. Dassou, D. Djidohokpin and M. Zountangni. / en jachère à Toucountouna.

herb up to $60 \mathrm{~cm}$ tall (fertile erect stems) and $1.2 \mathrm{~m}$ long (sterile stems prostrate), with woody rootstocks. Its leaves are alternate and simple. The species presents axillary flowers, solitary or in cymes appearing from March to April and in October. Its fruits (capsules) contain seeds densely covered with a brown tomentum. Biogeographically, $I$. beninensis is known from a few localities within phytogeographical districts of Bassila (in GSZ), Atacora Mountains and Borgou-Sud (in SZ). It occurs on ferruginous soils on crystalline rocks, or with concretions and breastplates or on poorly evolved and mineral soils in woodlands and savannah. Major parts of its habitats are known to be unprotected. In addition, populations of $I$. beninensis are highly fragmented due to agricultural intensification and conversion, its and because it is regarded as weed in the farmlands by some people.

\subsection{Methods}

\subsubsection{Sampling}

Previous studies by AKoÈgninou \& LisowsKi (2004) and AkoÈgninou et al. (2006) identified some sites (N'Dali, Pèrèrè and Tanguiéta) to host $I$. beninensis. Prior to the survey, a preliminary investigation was made in February 2017 to obtain first local people consent in the target zones. The diversity of sociolinguistic groups and the presence of the species were used as the main criteria in selecting localities.
Complementary exploration work was performed with local leaders, which helped to identify additional sites: Djougou, Natitingou and Toucountouna. The normal approximation of the binomial distribution was used in order to determine the adequate sample size for the ethnobotanical survey (AsSOGBADJo et al. 2011; VodouHê et al. 2010). For this, we carried out an exploratory survey with 30 informants in each area supplemented by pictures of the species and its description (Fig.2). The starting question was: Do you know and make use of $I$. beninensis? The proportion of positive answers recorded helped to determine the sample size through the formula of DAGNELIE (1998):

$$
\mathrm{n}=\frac{(\mathrm{z})^{2} \mathrm{p}(1-\mathrm{p})}{\mathrm{d}^{2}}
$$

Where $\mathrm{n}=$ sample size, $\mathrm{z}=$ level of confidence according to the standard normal distribution $=1.96$ (for a level of confidence of $95 \%$ ), $\mathrm{p}=$ estimated proportion of the population that presents the characteristic $=0.25$ (from the preliminary survey) and $d=$ tolerated margin of error (for example we want to know the real proportion within 5\%).

Therefore the sample size used for the full survey was 114 informants.

\subsubsection{Data collection}

Interviews were conducted individually and in focus group with local residents. Data were gathered from March to June 2017. They were related to: (i)- socio-demographic characteristics of the informants (age, gender, sociolinguistic group, profession and level of instruction), (ii)- ethnobotanical knowledge on the species (vernacular names, different uses, plant part (s) frequently used, collection site, methods of use, use level) and (iii)- conservation status of the species (habitat type, abundance, population status of the species, and threats). The questionnaire was translated orally into local languages of investigation areas with the help of local guides.

\subsubsection{Data analysis}

All gathered data were arranged in a matrix including ethnobotanical and sociolinguistic importance data for I. beninensis. Those data were processed by calculation of descriptive statistics (frequency and histogram). Parameters of concern were: number of informants per district, sociolinguistic group, gender, age category, profession and, according to instruction level, category of uses, use, habitat, threats, plant parts used, methods of traditional medicine preparation, and route of administration of the medicine. We provided descriptive statistics (minimum, maximum, mean and standard deviation) to produce statistics for each socio-professional variable. To test the equality of means and to assess the differences in means, we use the Kruskal-Wallis procedure due to the data which are non-normally distributed. Spearman rank correlation test was used to determine whether there was a significant correlation between the age of informants and the number of categories of uses reported by each informant. Proportion tests were used to determine if there is any significant difference between the use number of the species reported and used by informants according to sociocultural and phytogeographical parameters. To assess the use pattern 
of uses according to sociolinguistic groups, Principal Component Analysis was carried out. We used R.3.5.1 (Core Team 2018) for statistical analyses.

\section{RESULtS}

\subsection{Socioeconomic traits of informants}

Informants of $I$. beninensis live mostly in the Atacora Mountains and the South-Borgou district (respectively 40 and $32 \%)$. Other informants $(28 \%)$ were found in the Bassila district. Regarding the sociolinguistic group, informants were mainly Peulh and Yom (28\% each); followed by Waama (22\%), Gourmantché (11\%), Ottamari (7\%) and Bariba (4\%). Among them, men were the most represented (79\%). The proportion of middle-aged people (30 years $>$ age $\leq 59$ years) was higher $(79 \%)$ as compared to the adults (age $\geq 60$ years) $(17 \%)$ and the youngs (age $\leq 29$ years) $(4 \%)$. Farmers were the predominant profession among informants $(69 \%)$ followed by breeders $(25 \%)$, guides $(4 \%)$, students $(2 \%)$ and healers (1\%). Regarding the education level, $78 \%$ of informants were illiterates, whereas $18 \%$ had finished primary education, $4 \%$ secondary school and only $1 \%$ university.

\subsection{Local names and uses of I. beninensis among infor- mants}

A total of four local names were indicated for the species. Names given and their meaning depend upon the sociolinguistic groups. Most notably, Gourmantché participants from Tanguiéta mentioned "Miloriman" meaning "we are together", plant used for maintaining harmony within family or community. In Waama, the name "Tiyoko" characterises the plant of ancestors. "Kondorha" symbolises the female in Yom. "Leminpullo" highlights the climbing form of the species in Peulh sociolinguistic group.

Across study area, two use categories encompassing 12 use of $I$. beninensis were reported by the informants: medicine $(83 \%)$ and fodder (17\%). The frequency of citation (Fig. 3) indicated that, among the 12 reported uses, the most recurrent were the treatment of varicella $(19 \%)$ and of malaria $(18 \%)$, the fodder $(17 \%)$ and the treatment of fever $(15 \%)$.

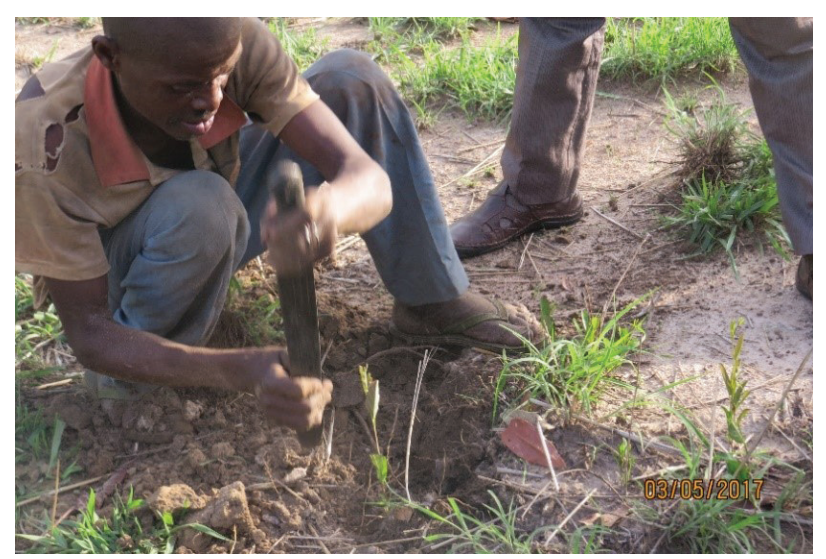

a)

\subsection{Plant parts of I. beninensis: preference, harvesting, preparation and administration}

Analysis of the results showed that people mostly prefer two main plant parts on I. beninensis. Leafy stem was the most

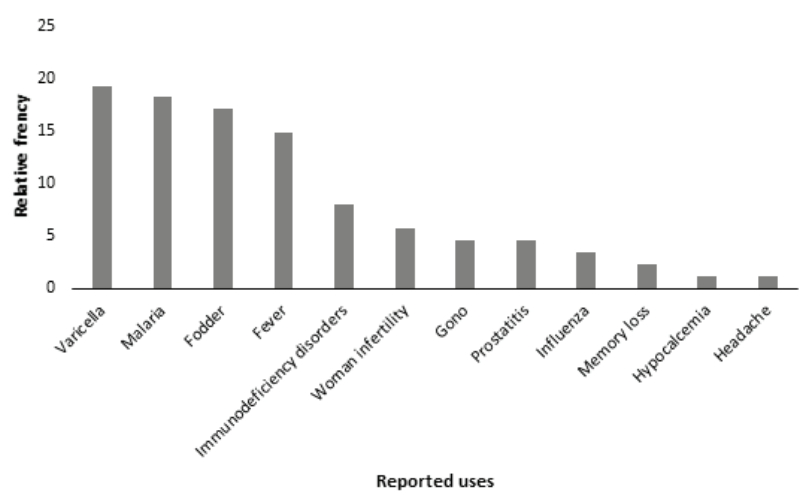

Fig. 3: Frequency of citation of the uses of Ipomoea beninensis in the area of investigation. / Fréquence de citation des utilisations d'I. Beninensis en region d'étude.

preferred ( $88 \%$ of the citation) by local people while the rootstock $(12 \%$ of the citation, Fig. 4 a, b) was known for only two uses.

Methods of preparation of the medicinal products include decoction $(72 \%)$ followed by crushing and homogenizing with water $(12 \%)$.

According to the local communities, a transdermal application of ointment from the transformation of leafy stem and dried weaverbird (Fig. 5) brings luck to the household. The described practice is also required to the treatment of the memory loss and to make people smarter. For the prostatitis treatment, potash is used as ingredient. Medicinal products are mostly consumed in liquid form or powder mixed with honey. For fodder use ( $16 \%$ of citations), leafy stems were grazed by all ruminants. Two ways of administration were recorded: oral $(74 \%)$ and dermal $(16 \%)$ routes. Plant parts and their preparations are summarized in Table 1.

Analysis of the consensus among informants for habitats of collection of the plant revealed that fallows had the highest frequency of citation (72\%), followed by farmlands (19\%) and woodlands (9\%).

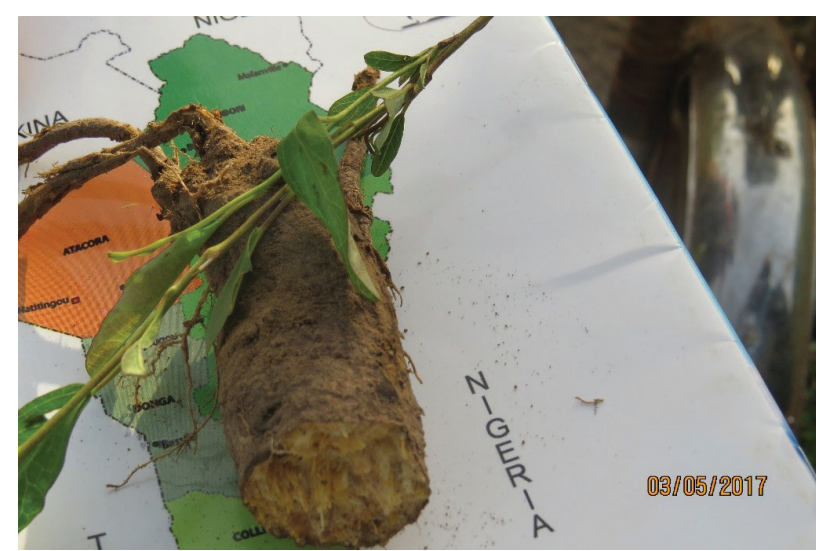

b)

Fig. 4: Harvest process (a) of the rootstock of Ipomoea beninensis by traditional practitioners at Tanguiéta. / Processus de récolte (a) du rhizom de Ipomoea beninensis (b) par les tradipraticiens à Tanguiéta. 


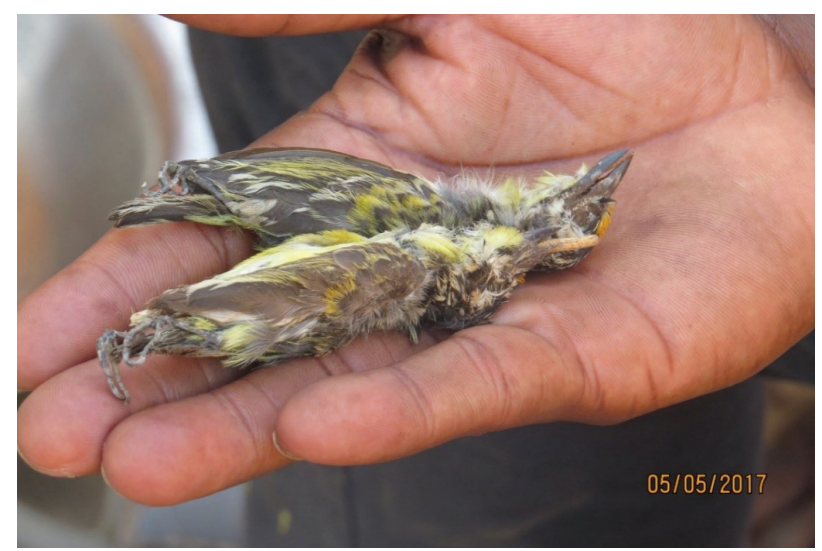

Fig. 5: Weaverbirds (Ploceus spec.) associated to the recipe preparation used in the treatment of the memory loss. / Tisserands (Ploceus spp.) associés à la préparation de recette utilisée dans le traitement de la perte de mémoire.
Informants belonging to Waama (mean \pm standard error; $1.84 \pm 0.24$ ) and Yom (mean \pm standard error; $1.65 \pm$ $0.17)$ reported less uses than Gourmantché $(2 \pm 0.36)$. The adult the interviewee, the higher is his knowledge on the species uses. Adult informants reported more uses $(4 \pm 2)$ than middle-aged $(2.41 \pm 0.35)$ and young informants $(1.95$ \pm 0.13 ). The number of significant uses per plant part was higher for leafy stem (10 uses) and rootstock ( 2 uses) (Table 1).

By considering the total number of reported uses, people from the Atacora Mountains reported the highest number of uses ( 9 uses) followed by Bassila district (7 uses), and the South-Borgou district (6 uses) (Table 2). Among the sociolinguistic groups, Waama people exhibited the highest number of uses (7 uses, Table 2). The situation was similar among the farmers ( 9 uses), breeders ( 5 uses), illiterates and

Table 1: Use of Ipomoea beninensis per plant part and use category in the study area: processing method, form of use, purpose of use in the study area. / Utilisation d'Ipomoea beninensis par organe de plante et par catégorie d'utilisation dans la zone d'étude: méthode de transformation, forme d'utilisation, finalité d'utilisation

\begin{tabular}{|c|c|c|c|c|}
\hline Plant part & $\begin{array}{l}\text { Use } \\
\text { category }\end{array}$ & $\begin{array}{l}\text { Processing } \\
\text { Method }\end{array}$ & $\begin{array}{l}\text { Form } \\
\text { of use }\end{array}$ & Purpose of use \\
\hline \multirow[t]{11}{*}{ Leafy stem } & Fodder & Fresh leaves & $\begin{array}{l}\text { Grazed directly by rumi- } \\
\text { nants }\end{array}$ & Fodder \\
\hline & \multirow[t]{10}{*}{ Medicine } & Boil leaves (decoction) & Drink the liquid & Fever \\
\hline & & Boil leaves (decoction) & Drink the liquid & Headache \\
\hline & & Boil leaves (decoction) & $\begin{array}{l}\text { Give the liquid to baby or } \\
\text { lactating mother }\end{array}$ & $\begin{array}{l}\text { Hypocalcemia and immu- } \\
\text { nodeficiency disorders }\end{array}$ \\
\hline & & Boil leafy stem (decoction) & Drink the liquid & Influenza \\
\hline & & $\begin{array}{l}\text { Knead leafy stem and weaverbird } \\
\text { (transform leafy stem and weaver- } \\
\text { bird into ointment) }\end{array}$ & $\begin{array}{l}\text { Transdermal application of } \\
\text { ointment }\end{array}$ & Memory loss \\
\hline & & $\begin{array}{l}\text { Dry and transform leafy stem, } \\
\text { weaverbird and chameleon in flour }\end{array}$ & $\begin{array}{l}\text { Add a spoon of flour to } \\
\text { two spoons of honey, mix } \\
\text { and drink two times daily }\end{array}$ & Memory loss \\
\hline & & Boil leafy stem (decoction) & Drink the liquid & Malaria \\
\hline & & $\begin{array}{l}\text { Boil leafy stem (decoction) + po- } \\
\text { tash }\end{array}$ & Drink the liquid & Prostatitis \\
\hline & & Boil leafy stem (decoction) & Drink the liquid & Varicella \\
\hline & & Boil leafy stem (decoction) & Drink the liquid & Woman infertility \\
\hline \multirow[t]{2}{*}{ Rootstock } & \multirow[t]{2}{*}{ Medicine } & $\begin{array}{l}\text { Add water to crushed rootstock } \\
\text { and filter }\end{array}$ & Drink the liquid & Gonoccocia \\
\hline & & Boil rootstock (decoction) & Drink the liquid & Woman infertility \\
\hline
\end{tabular}

\subsection{Socio-economic factors and use value of $I$. beninensis} in its distributional area

The total number of reported uses by informants was comprised between 1 and 6 in the study area (Table 2). KruskalWallis test showed that number of reported uses was not significantly $(\mathrm{p}=0.411)$ different among the three districts (Atacora Mountains: $1.838 \pm 1.191)$, Bassila (2.219 \pm $1.263)$ and South-Borgou $(2.160 \pm 1.375)$. The same tendency found for gender $(\mathrm{p}=0.137)$, profession $(\mathrm{p}=0.177)$ and education level $(p=0.284)$. On the other hand, there was a significant relationship $(\mathrm{p}<0.05)$ between overall knowledge of $I$. beninensis uses and sociolinguistic groups and age categories. Informants belonging to Peulh sociolinguistic group have more knowledge on the species use. men (12 uses each) and middle-aged (12 uses). A positive correlation (Spearman correlation test $r=0.300 ; p=0.003$ ) was found between the age of informants and the number of uses by each informant (Fig. 6).

The Principal Component Analysis (PCA) performed on uses and sociolinguistic groups explained a total variability of $40 \%$ on axis the first axis 1 and $34 \%$ on second axis (Fig. 7). Analysis of the both figures ( $a$ and $b$ ) revealed that varicella, fever, gonoccocia, prostatitis and headache were significantly (and positively) loaded into the first principal component (Dim1), axis on which Waama and Ottamari informants were strongly and positively associated. Thus, 


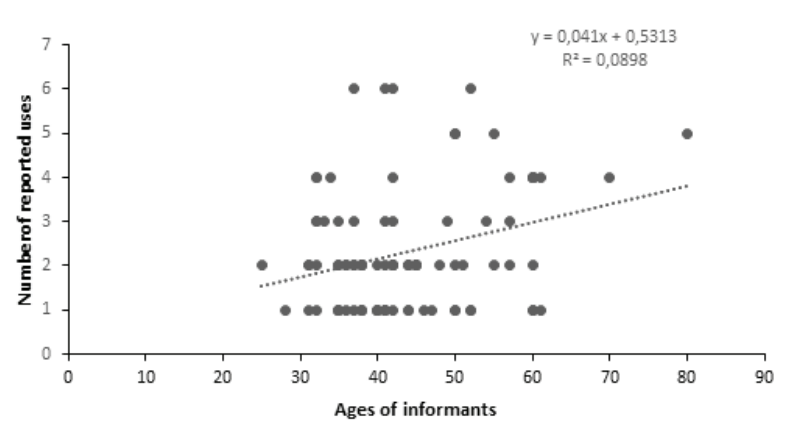

Fig. 6: Correlation between numbers of uses reported and ages of informants. / Corrélation entre le nombre d'utilisations déclarées et l'âge des informateurs.

Waama and Ottamari use I. beninensis for treating varicella, fever, gonoccocia, prostatitis and headache. In contrast, Peulh and Bariba informants (correlated negatively to axis 1) are unique informants using the plant for the treatment of Malaria, woman infertility and influenza and as fodder (Fig. $7 \mathrm{a}$ and $\mathrm{b}$ ). The principal component 2 (Dim2) positively correlated with immunodeficiency disorders, memory loss and hypocalcemia (Fig 7a) and Gourmantché and Yom (Fig 7b). Thus, the treatment of diseases such as immunodeficiency disorders, memory loss and hypocalcemia by I. beninensis is distributed in Gourmantché and Yom.

\subsection{Perceptions of habitats and conservation status of $I$. beninensis}

Two main habitats were recognized to host $I$. beninensis: woodlands and farmlands/fallows (Fig. 8). I. beninensis was reported to regenerate well in natural vegetation. For the majority of informants, exclusively the farmers $(69 \%)$, the species was scarce in all habitats.

Concerning soil types, I. beninensis is exclusively found on two soil types namely ferruginous and lateritic soils (Fig. 9). The majority of the informants (72\%) mentioned ferrugi-

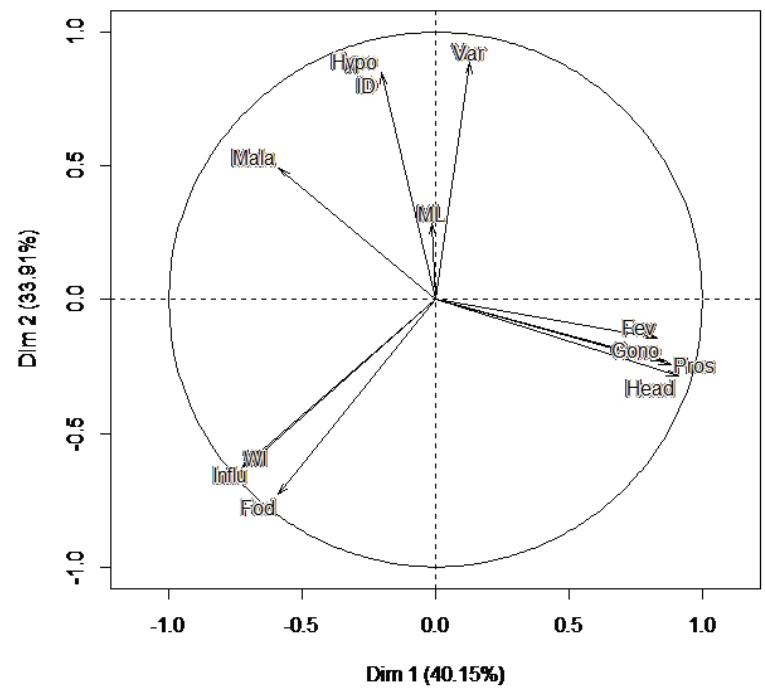

a) nous soil. All these informants live in Atacora Mountains and Bassila districts.

Almost all respondents stated that the population of I. beninensis has declined in recent times both in abundance and in distribution. The factors purportedly responsible for this decline were anthropogenic (agriculture, for the preparation of traditional drugs, grazing and urbanisation) and natural (climate change) (Fig. 10).

Agricultural factors contributing towards the decline included the destruction of natural habitats for conversion into cultivated land and by burning, uprooting and removing I. beninensis seedlings and saplings during farming activities (Fig. 11). All informants interviewed reported that the species is not conserved within its distribution area.

\section{Discussion}

\subsection{Traditional knowledge and local practices on I. beni- nensis}

This study revealed a significant difference of number of uses among ethnic groups and age categories in spite of disproportionate sample which hasn't affected the total number of reported uses (Chi-Sq $=0.202$; df. $=1 ; p=0.653$ ). Indeed, the Waama sociolinguistic group held the majority of knowledge regarding the high diversity of uses of the species (66.67\% of total uses). This sociolinguistic group is mostly found in Tanguiéta and Toucountouna (Atacora chain district), two main localities hosting high abundance of the species. This high use citation observed for the people belonging to main abundance area of the species can be explained by the ecological apparency hypothesis as originally suggested by FEENY (1976). It stipulates that people tend to collect and use plants that are available and easy to find. This situation is similar by considering informants of



b)

Legend: Influ: influenza, WI: woman infertility, Fod: Fodder, Mala: malaria, Fev: fever, Gono: gonoccocia, Pros: prostatitis, Head: headache, ID: immunodeficiency disorders, Hypo: Hypocalcemia, ML: Memory loss, Var: Varicella.

Fig. 7: Use of the organs of Ipomora beninensis (a) and its correlation with ethnical groups (b). / Utilisation des organes d'Ipomoea beninensis (a) et sa corrélation avec les groupes ethniques (b). 
Table 2: Variation of the total number of reported uses according to socio-economic factors.

BD : Bassila District: SBD : South-Borgou District: AMD : Atacora Mountains District: $n=$ number of informants : TNUV: Total number of uses per socio-cultural variable; TNUL: Total number of uses per locality; number in cells and in parenthesis in the cells respectively represents the total number of informants and of uses reported per modality of variable; TNUV bearing different letters were significantly different from others (Proportion test, $\alpha=0.05$ ).

\begin{tabular}{|c|c|c|c|c|c|c|c|}
\hline \multirow{3}{*}{$\begin{array}{l}\text { Socio-economic } \\
\text { variables }\end{array}$} & \multirow{2}{*}{\begin{tabular}{|l|} 
BD $(n=32)$ \\
Djougou \\
\end{tabular}} & \multirow{3}{*}{$\begin{array}{l}\text { SBD }(n=37) \\
\text { Pèrèrè } \\
(n=25)\end{array}$} & \multicolumn{4}{|c|}{$\operatorname{AMD}(n=45)$} & \multirow{3}{*}{ TNUV } \\
\hline & & & N'Dali & Natitingou & Tanguiéta & Toucountouna & \\
\hline & $(n=32)$ & & $(n=12)$ & $(n=8)$ & $(n=17)$ & $(\mathrm{n}=20)$ & \\
\hline \multicolumn{8}{|l|}{ Ethnic groups } \\
\hline Bariba & - & $3(2)$ & $2(0)$ & - & - & - & $2^{\mathrm{b}}$ \\
\hline Gourmantché & & & & & $12(0)$ & - & $2^{\mathrm{b}}$ \\
\hline Ottamari & & & & $8(2)$ & & - & $2^{\mathrm{b}}$ \\
\hline Peulh & & $22(5)$ & $10(2)$ & & & - & $5^{\mathrm{ab}}$ \\
\hline Waama & & & & & $5(2)$ & $20(5)$ & $7^{\mathrm{a}}$ \\
\hline Yom & $32(6)$ & & & & & - & $6^{\mathrm{ab}}$ \\
\hline Profession & & & & & & - & \\
\hline Breeder & $5(2)$ & $14(5)$ & $6(2)$ & & & $3(5)$ & $5^{\text {ac }}$ \\
\hline Farmer & $27(6)$ & $10(2)$ & $5(1)$ & $8(2)$ & $12(2)$ & $17(2)$ & $9^{a}$ \\
\hline Guide & & & & & $5(3)$ & - & $3^{\mathrm{bc}}$ \\
\hline Healer & & $1(2)$ & & & & - & $2^{\mathrm{bc}}$ \\
\hline Student & & & $1(2)$ & & & - & $2^{\mathrm{bc}}$ \\
\hline Education level & & & & & & - & \\
\hline None & $28(5)$ & $22(5)$ & $10(2)$ & $7(1)$ & $13(2)$ & $9(4)$ & $11^{\mathrm{a}}$ \\
\hline primary & $5(3)$ & $2(1)$ & $2(1)$ & & $2(2)$ & $9(4)$ & $7^{\mathrm{b}}$ \\
\hline secondary & & & & & $2(1)$ & $2(1)$ & $2^{\mathrm{c}}$ \\
\hline University & & & & $1(2)$ & & - & $2^{\mathrm{c}}$ \\
\hline Age category & & & & & & - & \\
\hline Young ( $\leq 29$ yrs) & $3(1)$ & $2(1)$ & & & & - & $1^{\mathrm{c}}$ \\
\hline Adult (30-59 yrs) & $27(5)$ & $18(5)$ & $8(1)$ & $8(1)$ & $11(4)$ & $18(5)$ & $12^{\mathrm{a}}$ \\
\hline Old $(\geq 60 \mathrm{yrs})$ & $5(5)$ & $4(2)$ & $2(1)$ & & $6(1)$ & $2(1)$ & $8^{\mathrm{b}}$ \\
\hline \multicolumn{8}{|l|}{ Gender } \\
\hline Men & $24(5)$ & $22(5)$ & $12(2)$ & $6(1)$ & $10(3)$ & $16(4)$ & $12 \mathrm{a}$ \\
\hline Women & $8(4)$ & $3(2)$ & & $2(1)$ & $7(1)$ & $4(2)$ & $7^{\mathrm{b}}$ \\
\hline TNUL & 6 & 5 & 3 & 2 & 4 & 9 & 12 \\
\hline
\end{tabular}

Peulh sociolinguistic group, which are transhumant, going over thus several areas. Our study showed an uneven distribution of the knowledge on I. beninensis, demonstrating that the species was used among few sociolinguistic groups. Farmers, mostly illiterates and middle-aged and adult men, recognize and frequently utilize the species. The dominance of these people as potential informants could be explained by the existence of the species in farmlands, which facilitates its recognition. This finding fits in with the statement of BELTRÁN-RodríGuez et al. (2014) that farming is a common activity that provides a particular contribution to ethnobotanical knowledge. Ethnobotanical knowledge about the species is also associated to education. Here, people having received school education hold the lowest number of uses. Many ethnobotanical studies assume that education level (notably university) causes the loss of indigenous languages (among indigenous communities) and associated knowledge (SAYnes-Vasquez et al. 2013; Dassou et al. 2015; Kouch-
ADÉ et al. 2016; OUACHINOU et al. 2017). If young people hold the lowest number of uses, this could be explained by the level of formal education that has a negative association with ethnobotanical knowledge (ARIAs 2009). Nevertheless, this is not always true because it also depends on heritage.

With regard to the importance of local names (about 1 name per sociolinguistic group), we conclude that I. beninensis is perfectly integrated to the cultural system of the ethnic groups distributed within its repartition area. It is the evidence that each people group hold a particular perception about the species. This observation is not specific to the endemic plant species but it is a general feature of biological resources found in given geographic area, as revealed by Adomou et al. (2018). I. beninensis plays an interesting role in maintaining the livelihood for most people in the rural communities in its distribution area, whereby its medicinal importance was as important as its fodder use, the species 


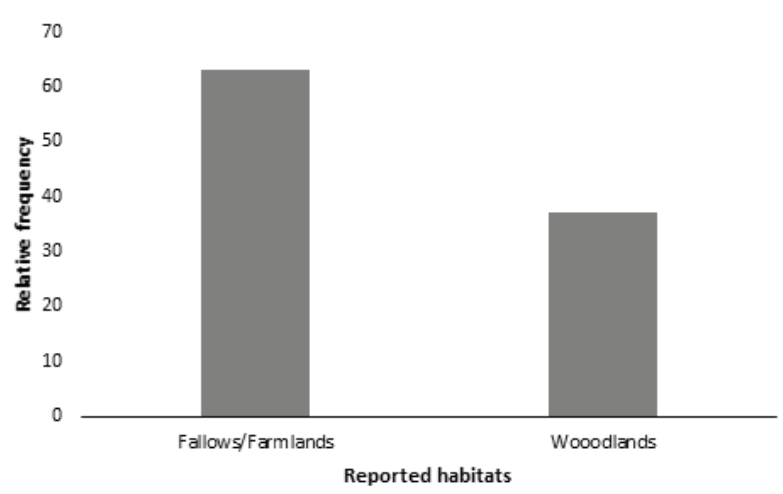

Fig. 8: Percentage distribution of the habitat harbouring Ipomoea beninensis. / Répartition en pourcentage de l'habitat abritant Ipomoea beninensis.

was cited in the treatment of 12 ailments with varicella, malaria and fever being frequently cited. As our work is the first study on the species, we suggest that phytochemical and pharmacological investigations should be done to reveal effective properties of the species; this will contribute to its potential valorisation.



Fig. 10: Percentage distribution of the factors mentioned as responsible for the population decline of Ipomoea beninensis in its distributional area. / Répartition en pourcentage des facteurs mentionnés comme responsables pour le déclin de la population d'Ipomoea beninensis.

The results showed that leafy stem was the most collected plant part for medicinal purposes across the distributional area. The preference for leafy stem can be attributed to the fact that the leaves (photosynthetic organ) are the biosynthesis source of secondary metabolites. They often contain secondary bioactive compounds that protect against herbivorous (SALIHU et al. 2018). Concerning the rootstock, its use can be associated with the mineral content and of this part of the plant. In general, organs are not harvested based on their availability in the region. In fact, each individual of the species disposes only one rootstock that is eventually harvested entirely. This harvesting method is an important factor in reducing the population of the species. Indeed, the organ over-harvesting for the preparation of medicinal products causes severe ecological impacts on the species. The most determinants are flowers, fruits, seeds, bark of stem and the roots and rhizomes. According to VerMEULEN (2006), over-exploitation of the roots and rhizomes is prejudicial for the individual of the species since this implies systematic destruction of the plant. In the long term, this can reduce the size of the population. Therefore, this kind of use can be regarded as unsustainable. To this, we will add the

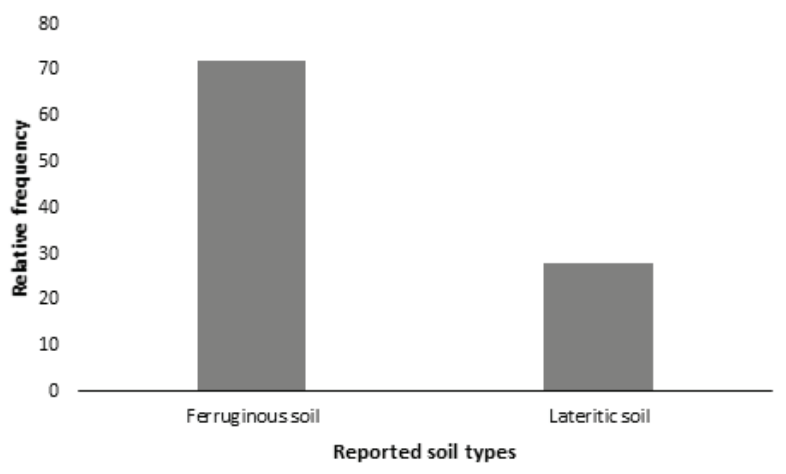

Fig. 9: Percentage distribution of the soil types harbouring Ipomoea beninensis. / Répartition en pourcentage des types de sols abritant Ipomoea beninensis.

conversion of natural habitats of the species in view of the scale of agricultural activities in the study area. Generally, in Benin, the process of deforestation, which is mainly due to shifting cultivation and timber exploitation, is happening at an alarming rate. During the last decades, vegetation has been vanishing at the rate of $2.3 \%$ per year, i.e. 70000 ha

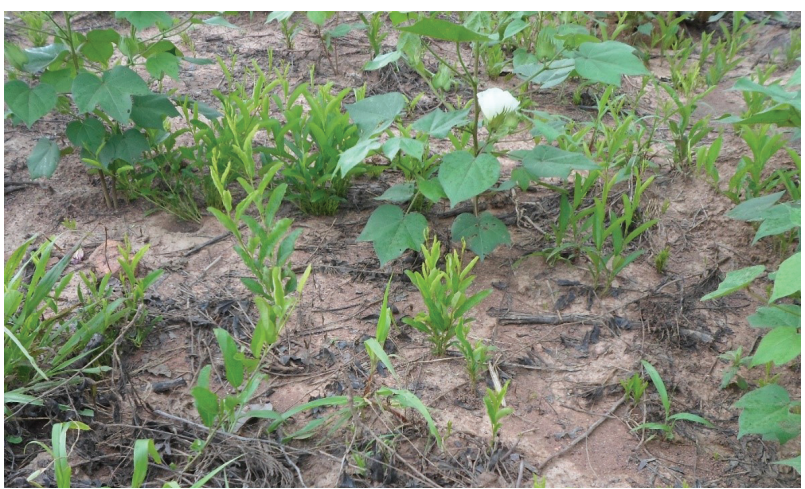

Fig. 11: Ipomoea beninensis growing in a cotton farm at Pèrèrè. / Ipomoea beninensis poussant dans une ferme cotonnière à Pèrèrè.

of forest cover every year (FAO 2010). This is particularly true in the distribution area of $I$. beninensis, where the majority of covered areas are reduced to some fragmented areas (Pers. obser.).

\subsection{Preliminary suggestions for conservation of I. beni- nensis}

One of outcomes of our study is to explore how information on local practices and indigenous knowledge on I. beninensis can be used in conservation measures and the sustainable management of the species. According to informants, $I$. beninensis has been reported as declining and this situation is due to the conversion of lands where the species is found into farmlands and the over-exploitation of its organs for the treatment of human pathologies and as fodder for animals. As regards these main threats, we suggest that different conservation measures be proposed. First, farmlands where the species is found could be converted to traditional agroforestry systems (on-farm conservation). This strategy, constituting a traditional conservation method, has been adopted for several species notably, that classified as endangered plant species according to the International Union for Nature 
Conservation (https://www.iucnredlist.org/) and ADOMOU et al. (2011). In these habitats, harvesting of organs of the species may be authorized. In addition, in the natural/seminatural and degraded lands (forests classified or not, savannahs and fallows), I. beninensis could benefit from particular management practices such as assisted natural regeneration, seeding or often sapling transplantation within the farmlands. The classified forest in N'Dali locality and Pendjari Park are the best candidates for supporting the conservation of the species because they already encompass some small remnant populations of the species. Furthermore, Benin authorities must include the species into the act of endangered species because many species protected under the law are on the pathway to recovery. Indeed, legislative attacks constrain citizens to adequately protect the most imperiled species. As far as species organs over-exploitation is concerned, we think that it is possible to substitute rootstocks by leaves for the preparation of medicinal drugs. Actually, we hypothesize that rootstocks and leaves contain same phytochemical compounds and could treat the same pathologies. For this, further laboratory studies are necessary in order to assess the phytochemical compounds and their pharmacological properties. As respects the over-exploitation of leafy stem as forage, it is important to sensitize the breeders on the respect of transhumance corridors. However, application of this measure needs to map current distribution area of the species including different corridors. The implementation of these conservation measures needs the involvement of local communities, scientists and Non-Governmental Organizations managers, other conservation-based agencies and extensionists.

\section{Acknowledgements}

We acknowledge the Rufford Small Grant Foundation which supported this work through the grant $\mathrm{N}^{\circ} 20742-1$. Furthermore we thank all the people of N'Dali, Pèrèrè, Djougou, Natitingou, Tanguiéta and Toucountouna for their cooperation; Eunock do-Régo, Abraham Favi, Donald Djidohokpin, Mathieu Zountangni, and Michel N'Tcha for their assistance in the field.

\section{Competing interests}

The authors declare that they have no competing interests.

\section{REFERENCES}

Adomou CA (2005): Vegetation Patterns and Environmental gradients in Benin. Implications for biogeography and conservation. - Ph.D Thesis, Wageningen University, 133p.

Adomou AC (2011): Plants. - In Neuenschwander P, Sinsin B, Goergen G (eds): Nature Conservation in West Africa: Red List for Benin, International Institute of Tropical Agriculture: Ibadan, Nigeria, 21-46.

Adomou AC, Dassou GH, Yédomonhan H, Favi GA, OuACHINOU JM-AS, ABOUdIA MJM \& HouÉNON GAH (2018): Analyse des connaissances traditionnelles et des déterminants relatifs à l'utilisation de Newbouldia laevis (P.Beauv.) Seem. (Bignoniaceae) au Sud-Bénin. - Afrique Sci 14 : 194205.

AkoÈGninou A \& Lisowski S (2004) : Notulae Florae Beninensis 2. Un Ipomoea (Convolvulaceae) nouveau et un Thunbergia (Acanthaceae) nouveau du Bénin. - Systematics Geogr Plants 74: 337-340.
Akoègninou A, VAn der Burg WJ \& VAn der Maesen LJG (2006): Flore Analytique du Bénin. - Backhuys Publishers, Leiden, Pays-Bas, 1034p.

Arias B (2009): Diversidad de usos, prácticas de recolección y diferencia según género y edad en el uso de plantas medicinales en Córdoba, Argentina. - Bol Latinoamericana Caribe Plantas Aromáticas 8: 389-401.

Assogbadjo AE, Glèlè Kakaï R, Adjallala FH, Azihou AF, Vodouhê GF, KyndT T \& CODJIA JTC (2011): Sociolinguistic differences in use value and use patterns of the threatened multipurpose scrambling shrub (Caesalpinia bonduc L.) in Benin. - J Med Plants Research 5: 1549-1557.

Beltràn-Rodríguez L, Ortiz-Sanchez A, Mariano NA, Maldonado-Almanza B \& Reyes-García V (2014): Factors affecting ethnobotanical knowledge in a mestizo community of the Sierra de Huautla Biosphere Reserve, Mexico. - J Ethnobiol Ethnomed 10: 14. doi: https://doi. org/10.1186/1746-4269-10-14.

Botha J, WitKowski ETF \& Shackleton CM (2004): The impact of commercial harvesting on Waburgia salutaris (pepper-bark tree) in Mpumalanga South Africa. - Biodivers Conserv. 13: 1675-1698. https://doi.org/10.1023/ B:BIOC.0000029333.72945.b0.

CONSERVATION INTERNATIONAL DATABASE (2005). http:// www.biodiversityhotspots.org/.

Dagnelie P (1998) : Statistique théorique et appliquée. Inférence statistique à une et à deux axis, Vol 2. - De Boeck University Press, Bruxelles.

Dassou GH, Yédomonhan H, Adomou AC, Ogni CA, Tossou GM \& AKò̀Gninou A (2015) : Facteurs socioculturels et environnementaux déterminant la connaissance ethnovétérinaire au Bénin. - Afrique Sci 11: 335-360.

DO-RÉGO ME (2017): Etude écogéographique, modélisation des habitats favorables et gap de conservation de 15 espèces des parents sauvages des plantes cultivées prioritaires pour la conservation au Bénin. - Master thesis, University of Abomey-Calavi, 49 p. Unpublished.

ECKert CG, SAmis KE \& LougheEd SC (2008): Genetic variation across species' geographical ranges: the central-marginal hypothesis and beyond. - Molecular Ecol 17: 11701188. doi: 10.1111/j.1365-294X.2007.03659.x.

Fandohan AB, Moutouama JK, Biaou SSH, GouwaKINNOU GN, Adomou AC (2015). Le réseau d'aires protégées Bénin-Togo assure-t-il la conservation de Thunbergia atacorensis (Acanthaceae)? - REV. CAMES 3 (2), 7 p.

FAOSTAT (2010): FAO Statistics Division, http://faostat. fao.org.

Gaoué OG, Kouagou M, Natta AK \& Gado C (2017): Response of a tropical tree to non-timber forest products harvest and reduction in habitat size. - PLoS ONE 12, 12p. https://doi.org/10.1371/journal.pone.0183964.

Gaoué OG \& TickTIN T (2007): Patterns of harvesting foliage and bark from the multipurpose tree Khaya senegalensis in Benin: Variation across ecological regions and its impacts on population structure. - Biol Conserv 137: 424-436. doi: 10.1016/j.biocon.2007.02.020.

Hahn K, Schmidt M, Thiombiano A (2018): The Use of Wild Plants for Food: a National Scale Analysis for Burkina Faso (West Africa). - Flora Vegetatio Sudano-Sambesica 21: 25-33.

Heinrich J \& Moldenhauer KM (2002): Climatic and Anthropogenic Induced Landscape Degradations of West Afri- 
can Dry Savanna Environments during the Later Holocene. - Quaternary International 93:127-137.

INSAE (Institut National de la Statistique et de l'Analyse Economique) (2013): Quatrième recensement général de la population et de l'habitation: Résultats provisoires. - MPPD : Cotonou, Benin.

IUCN (International Union for the Conservation of Nature): Glossary of definitions. - IUCN, 83p. (www.iucn.org), download on July 29, 2020.

Kouchadé AS, Adomou AC, Tossou GM, Yédomonhan H, DAssou GH \& AkoÈgninou A (2016): Étude ethnobotanique des plantes médicinales utilisées dans le traitement des maladies infantiles et vendues sur les marchés au sud du Bénin. - J Animal Plant Sci 28: 4418-4438.

Ouachinou JM-AS, Adomou AC, Dassou GH, YédoMONHAN H, Tossou GM \& AKoÈGninou A (2017): Connaissances et pratiques ethnobotaniques en médecines traditionnelles vétérinaire et humaine au Bénin : similarité ou dissemblance? - J Appl Biosci 113: 11174-11183.

Pouget M, Youssef S, Migliore J, Juin M, Médail F \& BAumel A (2013): Phylogeography sheds light on the central-marginal hypothesis in a Mediterranean narrow endemic plant. - Ann Bot 112: 1409-1420. doi: 10.1093/aob/ mct183.

Salihu T, Olukunle JO, Adenubi OT, Mbaoji C \& Zarma MH (2018): Ethnomedicinal plant species commonly used to manage arthritis in North-West Nigeria. - South African J Bot 118: 33-43. https://doi.org/10.1016/j.sajb.2018.06.004

Saynes-Vásquez A, Caballero J, Meavey J \& Chiang $\mathrm{F}$ (2013): Cultural change and loss of ethnoecological knowledge among the Isthmus Zapotecs of Mexico. - J Ethnobiol Ethnomed 9:40. https://doi.org/10.1186/1746-4269-9-40
Sexton JP, Mcintyre PJ, Angert AL \& Rice KJ (2009): Evolution and ecology of species range limits. Annual Review Ecol, Evol Systematics 40: 415-436. https://doi. org/10.1146/annurev.ecolsys.110308.120317

Schmidt IB, Mandle L, Ticktin T \& Gaoué OG (2011): What do matrix population models reveal about the sustainability of non-timber forest product harvest? - Journal Appl Ecol 48: 815-826. https://doi.org/10.1111/j.13652664.2011.01999.x

SCHMidT M (2018): New species records for the flora of Burkina Faso. - Flora Vegetatio Sudano-Sambesica. 21: 3-6. https://doi.org/10.21248/FVSS.21.55.

Schumann K, Wittig R, Thiombiano A, Becker U \& HAHN K (2011): Impact of land-use type and harvesting on population structure of a non-timber forest product-providing tree in a semi-arid savanna, West Africa. - Biol Conserv 144: 2369-2376.

Souto T \& TickTIN T (2012): Understanding interrelationships among predictors (age, gender, and origin) of local ecological knowledge. - Econ Bot 66: 149-164.

TickTIN T (2004): The ecological implications of harvesting non-timber forest products. - J Appl Ecol 41: 11-21. https:// doi.org/10.1111/j.1365-2664.2004.00859.x.

VermeUlen WJ (2006): Sustainable bark harvesting for medicinal use: matching species to prescription. - In "Trees for health - forever - Implementing sustainable medicinal bark use in Southern Africa" Willow Park, Johannesburg, South Africa.

Vodouhê FG, Coulibaly O, Greene C \& Sinsin B (2009): Estimating the Local Value of Non-Timber Forest Products to Pendjari Biosphere Reserve Dwellers in Benin. - Econ Bot 63: 397-412. https://doi.org/10.1007/s12231-009-91027. 